\title{
MANAJEMEN SUMBER DAYA MANUSIA ISLAM: \\ SEJARAH, NILAI DAN BENTURAN
}

\author{
Ihsan Rahmat* \\ $\&$ \\ Netta Agusti
}

\begin{abstract}
Human resource management (HRM) in Western perspectives continue to be questioned in the East, especially from Islamic academics. There is hope to implement religious teachings in the organizational sphere. Generally, this paper discusses issues in Islamic HRM, questioning the extent to which Islam (text and context) governs people in organizations. Putting forward the literature sourced from the pages of Ebsco and Emerald using the keywords "Islamic Human Resources Management." Found 96 journals, but only 21 contained the themes we meant. Then read intensively, make mapping, determine the main ideas of each journal, and group ideas based on themes. These themes were discussed: the internalization of Islam in HRM, Islamic values in HRM, developments in Muslim countries, and the challenges of Islamic HRM. This paper found religion entered the organizational realm not far after the discussion of industrial psychology was discussed. Using framework of 'the management theory jungle', the role of religion in organizations can be explained. HRM is a Western product that emerged after the industrial revolution. The argument positions Islam as a regulator of halal-haram restrictions on human activities in the organization. Furthermore, the cultural phenomenon above religion is also a hot issue. Managers know, understand, and acknowledge the goodness of Islam, but not yet for practice. So far, the expert study of Islamic HRM is still merely exploring values based on four sources, namely the Qur'an, Hadith, Ijma ', and Qiyash. Need best practice research, so that later it will be able to bring up the Islamic HRM curriculum.
\end{abstract}

Keywords: Islamic Human resource management, Islamic organizational culture, Ethic, Muslim world.

\section{PENDAHULUAN}

Manusia diyakini sebagai
daya yang paling esensial
merencanakan, memutuskan
menjalankan sebagian besar aktifitas
organisasi. Pengakuan tersebut mulai
disadari seiring dengan tuntutan kebutuhan
organisasi pasca revolusi industri. Taylor
(1911), sebagai proklamator scientific
management, menjawab fenomena

revolusi dengan memaksimalkan peran buruh. Beberapa strategi yang diterapkan seperti pembuangan gerak-gerik yang tidak perlu, memperhatikan kebersihan dan kesehatan buruh, hingga peningkatan upah. Sejumlah ahli, teknisi, dan konsultan organisasi turut mencoba berbagai eksperimen di ruang kerja, baik itu yang berhubungan langsung dengan buruh ataupun fasilitas penunjang. Praktik kerja

*Penulis adalah Dosen Jurusan Dakwah IAIN Bengkulu 
berbasis perbaikan terus-menerus dinilai mampu mengerahkan kemampuan manusia secara efektif dan efisien.

Meletakkan manusia sebagai inti organisasi, terus menjadi perhatian sampai sekarang. Dibuktikan dengan munculnya berbagai konsep mulai dari socialman era, personel management, human resources management, hingga human capital. Konsep tersebut terbaca mapan di dunia Barat, tetapi mengalami banyak benturan di dunia Timur, khususnya negara-negara Islam. ${ }^{i}$ Nilai-nilai seperti individualisme, materialisme, dan sekularisme telah menjadi dasar filosofis dalam konsep manajemen sumber daya manusia (MSDM). Ketika nilai di atas masuk ke dalam organisasi Islam, akan terjadi 'inappropriate' atau pemaksaan budaya organisasi (Branine dan Pollard, 2010: 715).

Pada akhirnya, hal tersebut terpaksa dilakukan karena konstruksi MSDM Islam atau organisasi yang menerapkan budaya Islam, belum terkonsep dengan baik. Kuchinke (2010) kemudian menganggap perlu merumuskan dan memperbaiki pemahaman sendiri tentang pentingnya mengembangkan individu dalam konteks bekerja di organisasi dan lembaga. Asumsi dasarnya adalah membangun suasana kerja dengan berpatokan pada nilai universal yang dianut oleh organisasi dan budaya yang ada di sekitar organisasi akan mampu melayani kebutuhan pekerja. Pertanyaan kemudian -sekaligus menjadi "big question" dalam tulisan ini-, sejauh mana ajaran Islam memberikan aturan main untuk mengatur manusia dalam organisasi?

Dalam konteks organisasi Islam modern yang mengakui manusia sebagai main actor, pertanyaan di atas menjadi relevan sekaligus mendesak untuk dibahas. Selain akan memberikan jawaban atas kontribusi Islam dalam organisasi, juga diyakini mampu menepis sebagian pandangan ahli manajemen bahwa agama atau ritual keagamaan seharusnya ditumpahkan di luar gerbang pabrik. Matiaske dan Gro"zinger secara kritis mempertanyakan kepentingan agama untuk masuk ke wilayah organisasi yang dianggap sekuler. ${ }^{\text {ii }}$ Terlebih adanya tesis yang menjelaskan agama menjadi bencana bagi organisasi. ${ }^{\text {ii }}$

\section{METODE KAJIAN}

Tulisan ini diharapkan dapat menambah literatur pada manajemen Islam, khususnya terkait isu-isu MSDM Islam. Dalam penggunaan referensi, sebagian besar didapatkan dari laman Ebsco (45 jurnal) dan Emerald (51 jurnal). Kami menggunakan kata kunci Islamic Human Resources Management. Tetapi, tidak menutup kemungkinan untuk memanfaatkan literature lain. Selama hal tersebut relevan dan membantu menjawab 
pertanyaan. Metode yang digunakan dalam kajian ini adalah scanning, intensif reading, coding, dan mapping. Setelah menggunakan teknik scanning, ternyata hanya 21 jurnal memuat tema yang kami maksud. Kemudian, jurnal-jurnal pilihan dibaca secara intensif, menentukan ide-ide pokok setiap jurnal, dan menggelompokkan ide berdasarkan tema. Tema-tema tersebut dibahas dalam kajian ini, yakni sejarah internalisasi Islam dalam MSDM, nilai-nilai Islam untuk MSDM, perkembangan MSDM Islam di negaranegara Muslim, dan tantangan MSDM Islam yang meliputi dilematis praktik, benturan budaya, dan kurikulum di perguruan tinggi.

\section{PEMBAHASAN}

\section{Internalisasi Islam dalam MSDM}

Memulai pembahasan dengan cara melacak kapan agama atau spiritualitas diakui sebagai bagian terpenting dalam organisasi. Penelusuran ini mengambil alur dari manajemen ilmiah, yakni menggunakan penjelasan Koontz tentang "Management Theory Jungle". Koontz dalam Wren mencatat 5 kelompok utama dalam pemikiran manajemen yang berkembang hingga akhir tahun 1950an, yakni: 1) Management Process School atau dikenal dengan kelompok tradisionalis. Mengakar pada Henri Fayol dengan menganggap manajemen sebagai sebuah proses guna menyelesaikan sesuatu melalui orang-orang lain dalam sebuah kelompok yang terorganisir; 2) Human Behavior School atau kelompok dengan pendekatan prilaku, human relations, beserta kepemimpinan. Mengakar pada Lilian M. Gilbreth dengan menggunakan psikologi dan psikologi sosial sebagai pendekatan untuk melihat sisi kemanusiaan seorang pekerja dalam manajemen dan organisasi.

Selanjutnya 3) Social System School atau kelompok dengan pendekatan sosial. Mengakar pada Chester Barnard. Memandang manajemen sebagai sebuah sistem sosial yang memuat unsur-unsur budaya interpersonal dalam sebuah grup; 4) Decision Theory School yang fokus pada analisis, pengembangan alternatif, dan pengambilan keputusan dalam manajemen. Pendekatan ini banyak digunakan oleh pakar ekonomi untuk melihat arah pengembangan organisasi; dan 5) Mathematical School yang memandang manajemen sebagai sebuah sistem yang berhubungan erat dengan perhitungan. Pendekatan ini berkontribusi pada penelitian dalam pengambilan keputusan, analisis, karena menggunakan simbol dan hubungan-hubungan dalam matematika. $^{\text {iv }}$

Walaupun konsep manajemen dilabeli sebagai Theory Jungle, kenyataanya adalah lima pendekatan ini 
dinilai tidak mampu menjawab tuntutan zaman pada waktu itu. Adapun orang yang mengkritik keras keilmuan manajemen adalah Peter F. Drucker. Drucker mengemukakan kegelisahannya karena manajemen selalu berorientasi pada faktor ekonomi dan hal tersebut dianggap gagal. Ia menyatakan:

"management has failed if it fails to produce economic result. It has failed if it does supply goods and service desired by the consumer at a price the consumer is willing to pay. It has failed if it does not improve or at least maintain the wealth producing capacity of the economic resources entrusted to it..."

Untuk menjawab permasalahan ini, Drucker membagi manajemen menjadi tiga ruang lingkup, yakni: managing a business, managing managers, managing workers and work. Ketiga lingkup ini dapat terpenuhi apabila manajemen menggunakan prinsip MBO (Management by Objective). Prinsip ini mengharuskan penetapan tujuan bersama dalam organisasi, sedangkan bawahan secara fleksibel menentukan rencana strategis untuk mencapai sasaran yang telah ditetapkan. Prinsip ini berhasil diimplementasikan pada General Electric Company. Melalui tiga prinsip ini, Drucker menaruh harapan pada perangkat organisasi untuk tidak selalu melihat manajemen sebagai faktor ekonomi, tetapi juga memperhatikan masalah lain seperti kesejahteraan pegawai dan masalah psikologi industri lainnya.

Perkembangan manajemen modern selanjutnya banyak dipengaruhi oleh kajian-kajian psikologi. Frederick Herzberg (1959) menemukan dual-factor theory untuk menjelaskan sikap karyawan dalam organisasi. Herzberg menjelaskan bahwa karyawan tidak puas dengan gaji yang rendah, level atau kondisi kerja yang tidak menyenangkan. Seperti halnya equity theory bahwa karyawan memperhitungkan apa yang ia berikan untuk organisasi dan membandingkan dengan apa yang ia terima. Untuk mengatasi hal tersebut, Herzberg menyerankan organisasi tidak hanya memberikan gaji yang sesuai, tetapi juga memberikan pengakuan, prestasi, kemajuan tangungjawab, dan sifat dari pekerjaan itu sendiri.

Douglas McGregor (1960) juga mengetengahkan teori X dan Y. McGregor membagi karyawan menjadi dua tipe yakni karyawan tipe $\mathrm{X}$ yang cenderung berperilaku negatif dan karyawan tipe $\mathrm{Y}$ yang cenderung positif. Teori ini terlihat jelas dalam organisasi, seringkali manajer menghadapi karyawan yang secara inheren tidak menyukai pekerjaan dan bila mungkin menghindarinya. Perilaku $\mathrm{X}$ ini menyebabkan karyawan dipaksa, diawasi, atau diancam dengan hukuman. Untuk memotivasi karyawan tipe $\mathrm{X}$, McGregor 
menyarankan organisasi menggunakan pressure, peraturan yang ketat dan kaku, ketentuan dan petunjuk teknis dalam bekerja secara terperinci.

Kemudian di tahun 1970-an, Chris Argyris dan Donal Schon mempromosikan teori tindakan melalui pembelajaran professional dan pembelajaran dalam organisasi. Teori ini sangat berkontribusi dalam pengembangan apresiasi tindakan pekerja dalam organisasi. Argyris dan Schon menyarankan organisasi harus memiliki peta mental guna mengetahui situasi para pekerja, karena dengan cara ini pemimpin bisa merencanakan, melaksanakan, dan meninjau tindakan. Teori-teori psikologi telah memberikan pengetahuan dalam dunia manajemen dan organisasi bahwa faktor psikis manusia harus dipertimbangkan.

Sejak masuknya kajian-kajian psikologi dalam dunia organisasi, manusia mendapatkan tempat tertinggi dan telah dianggap sebagai aset. Bahkan dari hasil kajian Tom Peters dan Robert Waterman di Jepang tahun 1982 menemukan bahwa pekerja membawa kehidupan agama ke dalam pekerjaan. ${ }^{\mathrm{vi}}$ Doktrin agama menjadi strategi utama untuk membangkitkan semangat dan motivasi pekerja. Manajer Jepang menggunakan doktrin Konghucu dan mengakumulasikannya dalam bentuk nilai-nilai yang mudah dibawa ke tempat kerja. Temuan ini diperoleh saat Peters dan
Waterman melakukan kajian pada 45 perusahaan teratas Fortune 500 yang bermasalah.

Pada saat yang sama, kajian tentang spiritualitas dalam organisasi mulai menunjukkan geliat. Spiritualitas oleh banyak ahli dimaknai secara beragam, baik yang berhubungan dengan agama maupun non-agama. Kajian Peter Sange tentang Strategies and Tools for Building a Learning Organization menjelaskan lima hal yang dapat membawa organisasi ke arah yang lebih baik, yakni: penetapan tujuan bersama, sistem berfikir, personal mastery, modal mental yang kuat, dan belajar bersama dalam tim. Pada tahap personal mastery, Sange mulai membicarakan sistem nilai yang berhubungan dengan emosional dan spiritualitas diri. Sange mengakui hal ini sangat abstrak, tetapi hasil kajiannya menyebutkan bahwa nilai abstrak inilah yang mampu membawa karyawan pada kepuasan kerja dan produktifitas. Spiritualitas semakin mendapat pengakuan dalam dunia manajemen dan organisasi saat Mitroff dan Denton mengumumkan hasil penelitiannya bahwa telah terjadi pergeseran paradigma dalam organisasi, yang awalnya values-based companies menjadi religion-based companies. Mereka juga memandang spiritual sebagai kunci sukses organisasi post-modern. ${ }^{\mathrm{vii}}$ 
Instensitas kajian-kajian agama dalam dunia organisasi dan manajemen mulai terlihat sejak awal 1980an. Kajian tentang etika bisnis Islam oleh Ahmad (1984) menunjukkan hal tersebut. Para ahli agama, psikologi, manajemen, dan organisasi mulai mempertimbangkan nilai dan prinsip Islam sebagai alternatif yang mampu mendongkrak kinerja organisasi. Maka banyak bermunculan kajian seperti perilaku organisasi dalam Islam (Wright, 1981), marketing model Islam (Shook \& Hassan, 1988), dan pandangan Islam tentang bank (Zangeneh, 1987).

Disertasi Seyed Mehdi Alvani (1981) banyak menampilkan pandangan Islam tentang aspek-aspek penting dalam organisasi, seperti: konsep Islam tentang otoritas (legitimasi, posisi, dan kompetensi), struktur organisasi, decision making, pendelegasian, komunikasi, negosiasi, motivasi, hingga proses evaluasi. Bahkan pada tahun 1982, Osman Albadri Abdalla masuk lebih dalam dengan menawarkan nuansa Islam sebagai pendekatan manajemen baru yang pada waktu itu gersang dari nilai dan norma. Kajian Islam dalam dunia manajemen dan organisasi terus mendapatkan perhatian serius. Jika sepanjang tahun 1980 terdapat sekitar 331 jurnal internasional yang menerbitkan kajian tentang Islamic Management dari berbagai perspektif, maka sepanjang tahun 1990 telah meningkat enam kali lipat yakni 1.842 jurnal. ${ }^{\text {viii }}$

Tulisan ini ingin mengatakan bahwa kajian psikologi telah memicu pengakuan organisasi terhadap nilai dan etika kerja. Tahun 1980an diyakini sebagai awal dimana pekerja mulai mengekspresikan berbagai nilai yang mereka yakini, termasuk agama. Ini cukup beralasan karena agama merupakan dasar bagi perilaku manusia. Di samping itu, organisasi juga mendukung hal tersebut untuk alasan produktifitas kerja. Pada akhirnya kami mempertimbangkan kembali ungkapan Koontz tentang "management thory jungle". Koontz menggambarkan berbagai perspektif yang mempengaruhi perkembangan pemikiran manajemen. Maka hingga tahap ini, kami mengatakan bahwa "jungle of management theory" kembali mengalami perkembangan yakni masuknya kelompok baru yang mendekati manajemen dari sisi spiritualitas (spiritual school). Maka pada akhirnya, apa yang diprediksi oleh praktisi di masa manajemen klasik menjadi terbukti bahwa manajemen itu juga parokial (sesuatu yang berkaitan dengan agama).

\section{Nilai Islam dalam MSDM}

Islam merupakan sumber nilai dalam organisasi. Islam memandang MSDM sebagai bagian inti organisasi yang berhubungan dengan perilaku pekerja, seperti hubungan antara satu dengan yang 
lain, pengembangan diri, dan yang lebih penting lagi adalah Islam membangun budaya organisasi melalui perilaku pekerja. Mellahi dan Budhwar dalam Sarwar dan Abugre menjelaskan beberapa prinsip dasar Islam yang sejalan dengan organisasi, yakni prinsip konsultasi (Syariah), kejujuran (al-Sidq), kepercayaan (alAmanah), keadilan dalam berurusan dengan karyawan (al-Adl), kerjasama (alTa'waan), dan prinsip keunggulan atau kesempurnaan (al-Ikhlas). ${ }^{\text {ix }}$ Khan et al., menambahkan beberapa prinsip, yakni persaudaraan (al-Ukhuwwah), kebajikan (al-Ihsan), pemenuhan kontrak (Ifa al'Aqd), hak pekerja (Haquq al-'Ibad), dan kompensasi yang adil (al-Ujrah). ${ }^{\mathrm{x}}$

Branine dan Pollard mencontohkan agenda berkumpul bersama pada organisasi modern, agenda ini telah dikenal di masa Rasulullah SAW dengan sebutan shura. ${ }^{\mathrm{xi}}$ Darul Arqam merupakan tempat berkumpul pertama dalam sejarah umat Islam. Lokasi ini menjadi tempat yang multifungsi, yakni tempat musyawarah, membangun strategi penyebaran Islam, sekaligus tempat bersembunyi dari kaum kafir di Mekkah. Rasulullah SAW memberikan banyak prinsip dalam shura, misalnya sikap menghargai pendapat orang lain walau pendapat tersebut datang dari kaum muda, memberikan porsi waktu untuk berbicara, mengambil keputusan melalui forum, dan lain sebagainya. Seperti praktik shura, praktik dari fungsi MSDM lainnya juga mendapat perhatian. Diantara praktik MSDM yang mendapat perhatian dalam Islam adalah rekrutmen, seleksi, pelatihan dan pengembangan, dan kompensasi.

\section{Rekrutmen}

Dalam proses rekrutmen, Islam menekankan prinsip keadilan ( $a l$-'Adl) untuk seluruh pelamar pekerjaan. Selain itu, Islam juga mewajibkan organisasi untuk memuat pilar-pilar Islam dalam persyaratan pelamar, seperti saleh, ihsan, jujur, dan profesional. Penelitian menemukan bahwa orang yang memiliki religiulitas akan cenderung bersikap amanah dalam bekerja. ${ }^{\text {xii }}$ Seorang Muslim yang bekerja dan memperhatikan kewajiban agamanya diyakini lebih bertanggung jawab dan dapat dipercaya karena dia bukan hanya mengemban amanah dari organisasi tetapi juga kepada Tuhannya. Persyaratan ini dinyatakan dalam surah An-Nisa ayat 58-59 disebutkan

"Sesungguhnya Allah SWT menyuruh kamu menyampaikan amanat kepada yang berhak menerimanya, dan (menyuruh kamu) apabila menetapkan hukum di antara manusia, supaya kamu menetapkan dengan adil. Sesungguhnya Allah SWT memberi pengajaran yang sebaik-baiknya kepadamu. Sesungguhnya Allah SWT adalah Maha mendengar lagi Maha melihat." 


\section{Seleksi}

Seleksi merupakan langkah lanjutan setelah proses rekrutmen dilaksanakan. Islam meletakkan prinsip al-'Adl dalam proses ini dan tidak memberikan ruang pilih kasih, praktik nepotisme penggunaan politik uang, atau melalui jalur tidak resmi (calo). Praktik kecurangan dalam seleksi umumnya terjadi di organisasi publik. Lemahnya kontrol negara dan buruknya integritas manusia menjadi sumber utama berjalannya proses kotor ini bertahuntahun. Iran merupakan negara yang menerapkan prinsip Islam dalam tata pemerintahan, tetapi nepotisme tumbuh subur. ${ }^{\text {xiii }}$ Selain prinsip $a l-' A d l$, al-Qur'an memberikan pedoman bagi organisasi untuk menemukan dua hal dalam diri calon pekerja, yakni integritas dan kompetensi. Dalam surah al-Qashash ayat 26 disebutkan

"Salah seorang dari kedua wanita itu berkata: "Ya bapakku, ambillah ia sebagai orang yang bekerja (pada kita). Karena sesungguhnya orang yang paling baik yang kamu ambil untuk bekerja (pada kita) ialah orang yang kuat lagi dapat dipercaya".

\section{Pelatihan dan Pengembangan}

Islam memandang pelatihan dan pengembangan bukan hanya dari sisi bertambahnya kemampuan intelektual, tetapi juga menekankan kedalaman moral yang bersumber pada spiritual atau agama. xiv Karena itu, materi dalam pelatihan atau pengembangan harus memuat nilai-nilai Etqan, Ihsan, dan alFalah. Konsep Etqan menekankan kesadaran untuk memperbaiki diri dalam upaya untuk menyelesaikan pekerjaan yang lebih baik. $^{\mathrm{xv}}$

Semangat perbaikan diri akan muncul ketika karyawan menyadari bahwa setiap pekerjaan yang dilakukan di organisasi diawasi langsung oleh Allah SWT. Ini berarti bahwa para pekerja dituntut untuk selalu melakukan yang lebih baik dan meningkatkan kontribusi dan kerja hasil mereka dengan cara belajar keterampilan baru dan memperoleh pengetahuan baru. Upaya memperbaiki diri membutuhkan gairah untuk menuju keunggulan atau dalam Islam dikenal dengan prinsip kemenangan (al-Falah). Karena nilai-nilai ini, keinginan untuk unggul dalam hal-hal pribadi dan profesionalitas merupakan suatu yang dianjurkan dalam Islam.

\section{Kompensasi}

Dari lima fungsi MSDM yang mendapatkan perhatian dalam Islam, praktik penggajian atau kompensasi merupakan praktik yang mendapatkan perhatian khusus. Baik dari sisi teks maupun praktik langsung yang ditunjukkan pada masa Khalifah. Prinsip al-'Adl tetap menjadi yang utama dalam penentuan gaji seseorang karyawan. Keadilan akan menghindari seseorang 
untuk curang dalam memberikan hak orang lain. Dalam surah Muthaffifin ayat 1-3 disebutkan

"Celakalah bagi orang-orang
yang curang (dalam menakar
dan menimbang), yakni orang-
orang yang apabila menerima
takaran dari orang lain mereka
minta dipenuhi. Dan apabila
mereka menakar atau
menimbang (untuk orang lain),
mereka mengurangi."

Khan et al., menjelaskan perlunya atasan untuk memasukkan al-Ukhuwwah dalam sistem penggajian. Prinsip alUkhuwaah cenderung diabaikan dalam tolak ukur pemberian gaji pegawai. ${ }^{\mathrm{xvi}}$ Jarang ditemukan organisasi Islam yang memperhitungkan pemberian gaji karyawan sesuai dengan jumlah anggota keluarga yang harus dinafkahi. Umumnya sistem penggajian menjadikan upah minimum regional atau daerah sebagai tolak ukur utama. Sehingga di organisasi Islam modern hampir tidak ditemukan bawahan yang mendapatkan gaji hampir sama dengan atasan, padahal kebutuhan dasar dan standar kehidupan mereka sebanding.

\section{Perkembangan MSDMI di Negara} Muslim

$\begin{array}{lcr}\text { Ada beberapa negara } & \text { yang } \\ \text { menerapkan } & \text { prinsip Islam dalam } \\ \text { organisasi, yakni Arab Saudi, Iran, } \\ \text { Kazakhistan, dan Malaysia. Di antara } \\ \text { keempat negara tersebut, Malaysia muncul }\end{array}$

sebagai negara baru yang menerapkan Islamisasi di berbagai sektor. Sejak 2005, Malaysia dianggap sebagai yang terbaik dan konsisten dalam menggali dan mengembangkan prinsip Islam di organisasi. Malaysia diakui sebagai negara Islam yang paling maju dan progresif dalam hal administrasi, ekonomi, dan pembangunan sosial. Malaysia juga dikenal secara internasional sebagai salah satu dari sedikit negara Islam yang telah memperkenalkan dan membentuk sistem keuangan Islam.

Dimulai dengan proses Islamisasi yang diprakarsai oleh Perdana Menteri Malaysia, Mahatir Mohammed, untuk menanamkan nilai-nilai Islam ke seluruh masyarakat di semua tingkat, mulai dari individu hingga institusi. Literatur manajemen Islam banyak muncul di Malaysia, bahkan dapat dikatakan sejak 2005 hampir setengah kajian manajemen Islam terbit di negara ini. Misalnya kajian Fontaine yang mencoba membangun metode crosscheck dengan muatan Islam untuk pemecahan masalah di organisasi. ${ }^{\text {xvii }}$ Lebih besar dari itu, Malaysia menciptakan sejarah lagi saat meluncurkan Sistem Manajemen Mutu Islam yang pertama di dunia, yaitu MS 1900 dari perspektif Islam. ${ }^{\text {xviii }}$ Saat ini, MS 1900 memiliki tiga tujuan yaitu: 1) menanamkan persyaratan Syariah ke dalam praktik manajemen mutu dengan penekanan pada manajemen 
berbasis nilai; 2) meningkatkan efektivitas dan efisiensi melalui praktek perilaku yang baik dan universal di semua tingkat organisasi; dan 3) meningkatkan kepatuhan dan kepercayaan Syariah di kalangan umat Islam dan pemangku kepentingan. Di saat Malaysia gencar mengkaji sistem Islam dalam manajemen, para ahli dan praktisi menanti kajiankajian serupa di negara muslim lainnya.

Jauh sebelum Islamisasi di Malaysia, studi-studi agama dalam manajemen berkembang pesat di Timur Tengah. Hashim menyebut kajian ini tidak seimbang, karena banyak negara yang memiliki penduduk muslim lain di kawasan Asia Tenggara seperti Malaysia, Indonesia, Thailand, Filipina, dan Brunai Darussalam, kurang mendapat perhatian. ${ }^{\text {xix }}$ Bahkan kajian MSDMI yang kredibel belum terlihat di negara-negara ini, kecuali Malaysia. Arab Saudi menjadi negara Islam yang paling sering menjadi lokus penelitian.

Permasalahan yang timbul di Arab Saudi adalah kebiasaan para manajer untuk menggunakan teks-teks Barat sebagai rujukan utama. Branine dan Pollard menjelaskan walau sudah terlihat ketidaksesuaian budaya Arab dengan Barat, para manajer tetap memaksakan praktik Barat. ${ }^{\mathrm{xx}}$ Selain karena penggunaan teks Barat yang berlebihan, Weir membeberkan penyebab lain, yakni manajer yang ada di kawasan Teluk kebanyakan memegang gelar dari universitas Amerika, Inggris, Perancis, Jerman dan Jepang. ${ }^{x x i}$ Manajer Teluk juga menerima pelatihan manajemen dalam tiap tahun dari manajer Amerika dan Inggris. Kekuatan bisnis global, difusi dari teori dan praktik manajemen kapitalis, kehadiran perusahaan multinasional, tingginya pemaparan manajemen Barat untuk karyawan lokal, semakin banyak karyawan asing, dan pengaruh-pengaruh media Barat seperti kegiatan, serta tekanan politik dan bahkan militer Barat, juga mempengaruhi praktik MSDM di Arab Saudi.

Permasalahan yang sama juga muncul di Iran, yakni penggunaan kurikulum manajemen Barat yang tidak terkontrol untuk sekolah bisnis, universitas, dan pelatihan-pelatihan di organisasi. Meskipun sudah terbukti terjadi gesekan nilai dalam praktik pekerjaan, yakni nilainilai individualistis dan materialis tidak sesuai dengan budaya masyarakat Iran yang kolektif, orientasi masa lalu, dan pendukung sistem hirarkis dalam pekerjaan, tetapi tetap saja dipaksakan. ${ }^{\text {xxii }}$

Razimi et al., berpendapat kebijakan penggunaan kurikulum manajemen Barat ini terpaksa dilakukan karena sulitnya menemukan bahan ajaran manajemen Islam yang siap pakai. xxiii Ada kemungkinan terjadi gap yang terlalu luas antara praktik manajemen Islam dengan 
teori yang ada, sehingga berdampak pada penggunaan kurikulum. Artinya, ada ketidakseriusan sarjana-sarjana manajemen Islam untuk menggarap bidang kajian yang luas ini. Untuk sementara Khan dan Seikh hanya mengusulkan pendidikan etika bisnis Islam dan tradisi spiritual sebagai kurikulum wajib di sekolah-sekolah. ${ }^{\text {xiv }}$

\section{Tantangan MSDM Islam}

\section{Implementasi Ajaran ke Praktik}

Tantangan utama dalam MSDM Islam adalah mempraktikkan nilai-nilai Islam dalam pekerjaan. Kebanyakan manajer tahu dan paham ketika ditanya tentang prinsip-prinsip Islam dalam bekerja, tetapi pengetahuan tersebut tidak lebih dari ucapan. Umat Islam umumnya tidak mencoba dan mengembangkan pemahaman agama secara mendalam. AlQur'an hanya sebagai bacaan dan hafalan tanpa memahami esensi dan makna. Orang-orang fasih dengan prinsip-prinsip dasar, tetapi kurang memahami untuk konteks muamalah. Budaya keberpihakan tetap mendapat ruang, sehingga praktikpraktik individualis, meterialis, ketidakadilan dalam rekrutmen, nepotisme dalam seleksi, tetap tumbuh subur. Fenomena ini disebut "unity of contradictions", yakni pekerja menggugurkan sistem manajemen Islam karena terdapat kontradiksi antara pengakuan dengan praktik. ${ }^{\mathrm{xxv}}$
Branine dan Pollard berpendapat lain, bahwa sulitnya implementasi praktik Islam karena penggunaan teks manajemen Barat yang berlebihan. ${ }^{\text {xxvi }} \mathrm{Hal}$ ini menyebabkan pekerja Islam kebingungan dalam membedakan MSDM Islam dengan MSDM konvensional. ${ }^{\text {xxvii }}$ Lebih dilematis lagi, pekerja Islam tidak sepenuhnya menyadari praktik MSDM konvensional lebih dominan dalam organisasi mereka. Temuan Hashim pada organisasi Islam di Malaysia mengungkap 40 persen dari pekerja muslim tidak mengerti dengan MSDM Islam. Kesimpulan akhirnya tetap mengatakan karyawan Muslim tidak memahami perbedaan mendasar antara MSDM Islam dan non-Islam. ${ }^{\text {xxviii }}$

Adapun Azmi menyimpulkan empat fungsi MSDM Islam yang dilaksanakan hingga batas tertentu, yakni seleksi, rekrutmen, pelatihan dan pengembangan. ${ }^{\text {xxix }}$ Di sisi lain, tiga praktik sumber daya manusia Islam yang dilaksanakan sampai batas moderat, yakni pengembangan karir, manajemen kinerja dan penghargaan praktek. Tetapi, temuan berikutnya mampu menjelaskan bahwa fungsi-fungsi di atas ternyata mengalami banyak kontradiksi dengan ajaran Islam.

1. Rekrutmen. Fenomena yang jelas terlihat dari penyebaran informasi rekrutmen oleh organisasi Islam yang mendahulukan umur, jenis klamin, bentuk fisik, status 
perkawinan, dan lain sebagainya.

Praktik ini merupakan bentuk diskriminasi yang menghapus nilai keadilan dan kesempatan.

2. Seleksi. Dalam surah al-Qashash ayat 26 menegaskan dua prinsip utama yang harus terpenuhi, yakni jujur dan professional. Lebih dari setengah dari total responden yang mewakili 58\% sangat setuju bahwa posisi seorang karyawan di tempat kerja harus didasarkan pada kualifikasi dan keterampilan. Terdapat lima syarat, yakni kompetensi, pengalaman, tanggung jawab, organisasi fit, dan reputasi dalam masyarakat. Pada praktiknya, unsur kekerabatan, jual-beli jabatan, dan "orang dalam" lebih ditonjolkan dari syarat di atas.

3. Kompensasi. Dari sekian banyak praktik MSDM, kompensasi yang mendapatkan perhatian khusus dalam Islam. Sifat pekerjaan, tugas dan tanggungjawab, hingga keluarga, mendapatkan perhatian dalam bentuk upah. Kurdi Ali melaporkan bahwa Khalifah Umar bin Khattab mengatur upah untuk bawahan dan deputi berdasarkan atas tingkat kesulitan pekerjaan, standar hidup di suatu daerah, sifat tugas, dan kebutuhan bawahan (seperti jumlah keluarga tanggungan). Upah dan kompensasi harus cukup untuk menunjang kehidupan pekerja beserta keluarga tanggungan. Ini tergambar jelas dalam dokumen al-Asthar. Dokumen tersebut menyatakan, “... beri mereka upah yang layak, yang akan memberikan mereka kekuatan untuk menahan godaan dan membuat mereka kurang rentan terhadap penyalahgunaan apa yang dipercayakan terhadap mereka". ${ }^{\mathrm{xx}}$ Sedangkan Khalifah Utsman bin Affan memberikan besaran upah berdasarkan tingkat senioritas. Dua praktik Khalifah menyempurnakan satu dengan yang lainnya. Hanya saja, fenomena yang belum terlihat bahkan oleh organisasi Islam yang mapan- adalah pengakomodiran kebutuhan keluarga dalam struktur gaji pekerja. Padahal, pemenuhan item ini dapat menghindari pekerja dari perbuatan buruk seperti korupsi dan penyalahgunaan wewenang.

\section{Benturan Budaya Lokal}


Globalisasi telah membuka akses negara menuju dunia yang tanpa batas. Akses paling jelas dirasakan dalam bidang ekonomi, teknologi, keamanan, dan politik. Kecepatan perubahan empat bidang ini seringkali direspon lambat oleh sosialkultural. Sehingga seringkali terlihat benturan dengan pemahaman lama yang masih dipegang oleh masyarakat. Pada ranah organisasi, benturan lebih terasa kompleks karena adanya tuntutat globalisasi, ketersediaan solusi yang kurang memadai, dan nilai yang dipegang oleh pekerja lokal.

Ali menyebut fenomena di atas dengan istilah crossvergence perspective, yakni negara -sadar atau tidakmendukung suatu bentuk budaya melalui proses perulangan dalam waktu yang relatif lama. ${ }^{x x i}$ Ketika terjadi perubahan yang begitu cepat, nilai-nilai dasar yang telah tertanam kuat, tidak mudah untuk digeser oleh nilai baru. Nilai-nilai bisnis yang berubah lebih cepat akan kontradiksi dengan nilai-nilai agama dan sosial. Keinginan karyawan untuk berbuat sesuai dengan keyakinan yang telah tertanam, menjadi luntur (kalah telak) karena nuansa budaya "terbiasa" dengan warisan-warisan praktik kerja lokal. Karena itu, penjelasan terkait benturan manajemen Barat dengan budaya lokal dapat dipahami. Sehingga cara yang paling bijak adalah mengembangkan system kerja sendiri berlandaskan pada budaya lokal.

\section{Kurikulum MSDM Islam}

Tiga dekade silam, Rahwar dan AlBuraey (1992) didukung oleh Bjerke dan Al-Meer (1993) mengatakan "western theories of work values may also be inappropriate for Islamic countries." Menariknya adalah meskipun terbukti terjadi 'inappropriate', tetap ada keinginan yang kuat dari organisasi Islam untuk terus mempelajari manajemen Barat sebagai sarana mendukung praktik bisnis lokal. ${ }^{\text {xxxii }}$ Fenomena yang berkembang menunjukkan adanya keenganan para praktisi untuk merumuskan dan menggali konsep Islam, di sisi lain kurangnya gairah akademisi untuk mengkaji dan mengekstrak praktik yang sudah ada. Dampaknya kemudian adalah jauh lebih mudah bagi mereka untuk mengimpor model siap pakai dari manajemen Barat, ketimbang mengembangkan dan menerapkan pemikiran manajemen mereka sendiri.

Hampir tidak ada penelitian empiris yang kredibel yang telah meneliti praktek HRM dari perspektif manajemen Islam. Literatur manajemen juga terbatas dalam mengungkap kesenjangan yang ada antara teori manajemen dalam Islam dan praktek manajemen di negara-negara Arab. Di negara Arab, pembicaraan tentang Islam dalam konteks global terkonsentrasi pada bidang hukum atau yang dikenal dengan 
hukum syariah. Sementara bidang ekonomi dan manajemen yang tersisa diadopsi dari Barat.

Ada beberapa masalah lain yang menyebabkan MSDM Islam sulit dirumuskan. Dari sisi dunia organisasi Islam, seringkali ditemukan praktik rekrutmen dan seleksi yang tidak mendukung karir akademisi Islam. Tampaknya, manajer lebih percaya dengan kemampuan yang dimiliki oleh akademisi lulusan kampus non-Islam. Anggapan Islam sebagai pengatur nilai halal dan haram terbangun, sehingga cukup diselesaikan dengan masa training. Praktik semacam ini turut mempersulit perkembangan praktik MSDM Islam. Asumsi dasarnya kebijakan SDM Islam yang dicetuskan oleh manajer senior akan mudah diterima ketika bawahan telah memiliki pondasi dan dasar filosofi yang telah dipelajari di kampus. Asumsi ini didukung oleh Tayeb (1996) bahwa karyawan di organisasi membawa warisan budaya mereka ke tempat kerja, termasuk nilai-nilai yang berhubungan dengan pekerjaan dan keyakinan agama. ${ }^{\text {xxiii }}$

Dari sisi akademisi, persoalan lebih banyak terlihat pada tataran minimnya kemampuan metodologi dan analisa untuk mengangkat best practice organisasi Islam. Hal ini disebabkan oleh berbagai faktor seperti kurangnya akademisi yang pure memahami manajemen Islam. Umumnya kampus Islam menarik pengajar manajemen dari kampus non-Islam. Keterbatasan ini memiliki efek domino pada keinginan pengajar untuk tetap menggunakan referensi-referensi Barat. Saat menjelaskan kasus pada organisasi Islam, tidak jarang teori dan konsep Barat yang digunakan untuk menjelaskan kasus. Fenomena ini yang dikatakan sebagai 'inappropriate' atau pemaksaan konsep. Pada akhirnya, tantangan selanjutnya adalah bagaimana merumuskan kurikulum yang tepat untuk MSDM Islam. Penetapan ini harus berdasar pada praktik dan kajian para akademisi. Tanpa permulaan ini, sulit bagi akademisi untuk menentukan pelajaran yang sesuai di bangku perkuliahan.

\section{KESIMPULAN}

Islam merupakan agama rahmatan lil 'alamin (way of life). Argumen tersebut menjadi dasar untuk mengatakan seluruh sendi kehidupan -termasuk berorganisasiyang ada sekarang hingga masa mendatang, sudah diatur dalam al-Qur'an dan diperinci melalui sunnah Rasulullah SAW dan Khalifah Ar-Rasyidin. Ini akan menggeser posisi Islam yang ditempatkan sebagai pengatur halal-haram dalam aktifitas organisasi. Diketahui bahwa jauh sebelum konsep personalia lahir, Islam telah mempraktikkan cara menyantuni manusia dalam organisasi. Praktik yang baik ini 
terlambat untuk diafirmasi, dikaji, dan dimunculkan dalam bentuk tulisan. Bahkan hingga saat ini, MSDM Islam masa lalu masih jarang disorot.

Sekali lagi, kajian telah dimulai, walau masih sangat terbatas. Negara Islam atau dengan mayoritas penduduk Islam terus melakukan berbagai cara untuk hal ini. Melalui Islamisasi kehidupan bernegara, menerbitkan undang-undang nasional, atau dengan mendukung kebijakan Islam di organisasi. Tantangan ke depan adalah memperkuat praktik Islam, menyelaraskan kebutuhan budaya lokal dengan nilai yang dianjurkan Islam, dan membuat sebuah kurikulum MSDM Islam.

Tulisan ini memberikan implikasi tentang pentingnya membangun kebijakan SDM dimulai dari manajer senior yang memiliki sifat 'alim. Bukan hanya sekedar paham, tetapi juga menjiwai agama. Ini diyakini mampu menutup kesenjangan antara aturan teks dengan tataran praktik. Kemudian, perlu menemukan pola kerja MSDM Islam di masa silam dari praktik yang dijalankan Rasulullah SAW, Sahabat, Tabi' in, hingga Tabi'ut Tabi'in. Juga perlu menghadirkan berbagai best practice penyelenggaraan MSDM di organisasi Islam modern. Melalui sistem berpikir seperti ini diharapkan mampu melahirkan MSDM model Islam, serta mempermudah perumusan kurikulumnya.
${ }^{\mathrm{i}}$ Bjorn Bjerke dan Abdulrahim Al-Meer, "Cultures Consequences: Management in Saudi Arabia", Leadership and Organization Development Journal, Vol. 14, No. 2, 1993. hlm. 31. Lihat juga Mawdudur Rahman dan Muhammad AlBuraey, "An Islamic Perspective of Organizational Controls and Evaluation", American Journal of Islamic Social Sciences, Vol. 9, 1992. hlm. 491.

ii Wenzel Matiaske dan Gerd Gro"zinger, "Religion and The Organisation Man", Management Revue, Vol. 21, No. 21, 2010. hlm. 5.

iii Emma Bell,"Towards a Critical Spirituality of Organization", Culture and Organization Vol. 14, No. 3, 2008. hlm. 293. Juga Sonja Gallhofer dan Jim Haslam, "Accounting and Liberation Theology: Some Insights for The Project of Emancipatory Accounting", Accounting, Auditing and Accountability Journal, Vol. 17, No. 3 , 2004. hlm. 383.

iv Daniel Wren, "The Evolution of Management Thought", (New York: John Wiley and Sons, 1987). hlm. 355-356.

v Peter Drucker, "The Practice of Management", (New York: Harper \& Row, 1954), hlm. 8 .

vi Ihsan Rahmat, "Melacak Sejarah Pemikiran dan Perkembangan Manajemen Dakwah". Proceeding Discussion Series on Da'wah Management, 2017. Yogyakarta: UIN Sunan Kalijaga. hlm. 20.

vii Ian Mitroff dan Elizabeth A. Denton, "A Study of Spirituality in The Workplace", Sloan Management Review, Vol. 40, 1999. hlm. 90.

viii Ihsan Rahmat, "Melacak Sejarah Pemikiran dan Perkembangan Manajemen Dakwah". Proceeding Discussion Series on Da'wah Management, 2017. Yogyakarta: UIN Sunan Kalijaga. hlm. 22.

ix Shagufta Sarwar dan James Baba Abugre, "An Assessment of Islamic Work Ethics of Employees in Organizations: Insights from The United Arab Emirates", Problems of Management in The 21 Century, Vol. 6, 2013. hlm. 62.

${ }^{x}$ Bilal Khan, Ayesha Farooq dan Zareen Hussain, "Human Resource Management: An Islamic Perspective", Asia-Pacific Journal of Business Administration, Vol. 2, No. 1, 2010. hlm. 29.

xi Mohamed Branine dan David Pollard, "Human Resource Management with Islamic Management Principles: A Dialectic for a Reverse Diffusion in Management", Personnel Review, Vol. 39, No. 6, 2010. hlm. 717.

xii Junaidah Hashim, "Islamic Revival in Human Resource Management Practices Among Selected Islamic Organisations in Malaysia", International Journal of Islamic and Middle Eastern Finance and Management Vol. 2, No. 3, 2009. hlm. 254. 
xiii Hamid Yeganeh dan Zhan Su, "An Examination of Human Resource Management Practices in Iranian Public Sector", Personnel Review, Vol. 37, No. 2, 2008. hlm. 216.

xiv Abderrahman Hassi, "Islamic

Perspectives on Training and Professional Development", Journal of Management Development Vol. 31, No. 10, 2012. hlm. 1030.

${ }^{x v}$ Mohamed Branine dan David Pollard,

"Human Resource Management with Islamic Management Principles: A Dialectic for a Reverse Diffusion in Management", Personnel Review, Vol. 39, No. 6, 2010. hlm. 720.

xvi Bilal Khan, Ayesha Farooq dan Zareen

Hussain, "Human Resource Management: An Islamic Perspective", Asia-Pacific Journal of Business Administration, Vol. 2, No. 1, 2010. hlm. 29.

xviiRodrigue Fontaine, "Problem Solving: An Islamic Management Approach", Cross Cultural Management: An International Journal, Vol. 15, No.3, 2008. hlm. 264-274.

xviii Siti Arni Basir dan Ilhaamie Abd. Ghani Azmi, "Malaysian Islamic Quality Management System MS 1900 from an Islamic Perspective: An Implementation Model", Jurnal Syariah, Vol. 19, No. 2, 2011. hlm. 85-106.

xix Junaidah Hashim, "Human Resource Management Practices on Organisational Commitment The Islamic Perspective", Personnel Review, Vol. 39, No. 6, 2010. hlm. 786.

xx Mohamed Branine dan David Pollard, "Human Resource Management with Islamic Management Principles: A Dialectic for a Reverse Diffusion in Management", Personnel Review, Vol. 39, No. 6, 2010. hlm. 713.

xxi Weir dalam Mohamed Branine dan David Pollard, "Human Resource Management with Islamic Management Principles: A Dialectic for a Reverse Diffusion in Management", Personnel Review, Vol. 39, No. 6, 2010. hlm. 715.

xxii Hamid Yeganeh dan Zhan $\mathrm{Su}$, “An

Examination of Human Resource Management Practices in Iranian Public Sector", Personnel

Review, Vol. 37, No. 2, 2008. hlm. 208-209.

xxiii Dalam Muhammad Habib Rana dan

Muhammad Shaukat Malik. "Human Resource Management from an Islamic Perspective: A Contemporary Literature Review", International Journal of Islamic and Middle Eastern Finance and Management, Vol. 9, No. 1, 2015. hlm. 110.

xxiv Muhammad Burdbar Khan dan Naeem Nisar Sheikh, "Human Resource Development, Motivation and Islam", Journal of Management Development, Vol. 31, No. 10, 2012. hlm. 1030.

${ }^{\mathrm{xxv}}$ Abbas J. Ali, "Business and Management Environment in Saudi Arabia: Challenges and Opportunities for Multinational Corporations", (New York: Routledge, 2008). hlm. 700.
${ }^{x x v i}$ Mohamed Branine dan David Pollard, "Human Resource Management with Islamic Management Principles: A Dialectic for a Reverse Diffusion in Management", Personnel Review, Vol. 39, No. 6, 2010. hlm. 713.

xxvii Ilhaamie Abdul Ghani Azmi, "Islamic Human Resource Practices and Organizational Performance: A Preliminary Finding of Islamic Organizations in Malaysia”, Journal of Global Business and Economics, Vol. 1, No. 1, 2010. hlm. 41.

xxviii Junaidah Hashim, "Islamic Revival in Human Resource Management Practices Among Selected Islamic Organisations in Malaysia", International Journal of Islamic and Middle Eastern Finance and Management Vol. 2, No. 3, 2009. hlm. 262.

xxix Ilhaamie Abdul Ghani Azmi, "Islamic

Human Resource Practices and Organizational Performance: A Preliminary Finding of Islamic Organizations in Malaysia”, Journal of Global Business and Economics, Vol. 1, No. 1, 2010. hlm. 27.

${ }^{x x x}$ Abbas J. Ali, "Islamic Challenges to HR in Modern Organizations", Personnel Review, Vol. 39, No. 6, 2010. hlm. 699.

xxxi Abbas J. Ali, "Islamic Challenges to HR in Modern Organizations", Personnel Review, Vol. 39, No. 6, 2010. hlm. 695.

xxxii dalam Ihsan Rahmat, "The Celestial

Management: Ikhtiar Mewujudkan Budaya

Organisasi Islam", Jurnal Manajemen Dakwah, Vol. 2, No. 1, 2016. hlm. 20.

xxxiii Mohamed Branine dan David Pollard,

"Human Resource Management with Islamic Management Principles: A Dialectic for a Reverse Diffusion in Management", Personnel Review, Vol. 39, No. 6, 2010. hlm. 714. 